\title{
PERANCANGAN SISTEM INFORMASI RUTE BUS RAPID TRANSIT (BRT) DI KOTA CIREBON BERBASIS WEBSITE (STUDI KASUS PT. BIMA INTI GLOBAL)
}

\author{
Hendra Wijaya ${ }^{1}$, Selvi Feliyanti ${ }^{2}$, Lena Magdalena ${ }^{3}$, Reza Ilyasa $^{4}$ \\ Universitas Catur Insan Cendekia \\ J1. Kesambi 202, Kota Cirebon, Jawa Barat Tlp : (0231) 220250 \\ e-mail : hendrawijaya110011@gmail.com ${ }^{1}$, selvifelinyati099@gmail.com² \\ lena.magdalena@cic.ac.id ${ }^{3}$, reza.ilyasa@cic.ac.id ${ }^{4}$
}

\begin{abstract}
ABSTRAK
Tranportansi sangat menunjang kelancaran dan kemudahan masyarakat dalam melakukan aktivitas seharihari. Transportasi harus didukung dengan kualitas dan pelayanan yang baik. Sistem transportasi yang tertib, aman, selamat, nyaman, cepat, teratur, lancar dan dengan biaya yang terjangkau diperlukan masyarakat dalam mendukung aktifitasnya. Oleh sebab itu, penyelenggara sistem transportasi harus mengelola transportasi terutama transportasi publik secara efektif dan efisien serta memberikan kenyamanan kepada masyarakat. Mengenal transportasi Bus Rapid Transit yang disingkat BRT atau populer di Indonesia dengan sebutan busway adalah sistem transit massal berbasis bus yang memberikan mobilitas cepat, nyaman dan berbiaya rendah dalam pelayanannya sebagai angkutan dalam perkotaan. Pemerintah Kota Cirebon juga sudah menerapkan moda terbaru tersebut dengan nama Bus Trans Cirebon yang mulai beroperasi pada tanggal 12 April 2021. Dengan transportasi ini, diharapkan dapat menjadi salah satu alternative untuk mengurangi kemacetan, menunjang kelancaran dan kemudahan aktivitas masyarakat. Dan juga dapat merasakan kenyaman fasilitas yang disediakan dengan berbiaya rendah dan terjangkau. Dalam penelitian ini membahas mengenai perancangan sistem informasi membantu membuat sistem informasi rute Bus Rapid Transit (BRT) untuk dipakai masyarakat Cirebon. Sistem ini juga membantu memudahkan masyarakat dalam mendapatkan informasi rute, halte dan jadwal keberangkatan Bus Rapid Transit (BRT). Dengan adanya sistem ini juga memudahkan admin perusahaan dalam mengelola seperti tambah, edit dan hapus data rute, data halte, dan jadwal keberangkatan Bus Rapid Transit (BRT).
\end{abstract}

Kata Kunci : Sistem, Informasi, BRT

\begin{abstract}
Currently, public transportation is also very supportive of the smoothness and convenience of the community in carrying out their daily activities. Transportation must be supported by good quality and service. An orderly, safe, safe, comfortable, fast, regular, smooth and affordable transportation system is needed by the community to support its activities. Therefore, the organizers of the transportation system must manage transportation, especially public transportation, effectively and efficiently and provide convenience to the community. Getting to know Bus Rapid Transit transportation, which is abbreviated as BRT or popularly known in Indonesia as busway, is a bus-based mass transit system that provides fast, convenient and low-cost mobility in its services as urban transportation. The Cirebon City Government has also implemented the latest mode with the name Trans Cirebon Bus which will start operating on April 12, 2021. With this transportation, it is hoped that it can be an alternative to reduce congestion, support the smoothness and ease of community activities. And also can feel the comfort of the facilities provided at a low cost and affordable. This study discusses the design of information systems to help create an information system for Bus Rapid Transit (BRT) routes for use by the people of Cirebon. This system also helps make it easier for the public to obtain route information, bus stops and departure schedules for Bus Rapid Transit (BRT). This system also makes it easier for company admins to manage such as adding, editing and deleting route data, bus stop data, and Bus Rapid Transit (BRT) departure schedules
\end{abstract} Keywords: System, Information, BRT

Perancangan Sistem Informasi Rute Bus Rapid Transit (BRT) di Kota Cirebon Berbasis (Studi Kasus: PT. Bima Inti Global)-(Hendra Wijaya, Selvi Feliyanti, Lena Magdalena, Reza Ilyasa) 


\section{PENDAHULUAN}

Transportasi adalah perpindahan manusia atau barang dari satu tempat ke tempat lainnya dengan menggunakan sebuah kendaraan yang digerakkan oleh manusia atau mesin. Tranportasi menjadi salah satu elemen yang sangat berperan penting dalam pembangunan Indonesia. Transportasi publik sangat menunjang kelancaran dan kemudahan masyarakat dalam melakukan aktivitas sehari-hari. Transportasi harus didukung dengan kualitas dan pelayanan yang baik. Sistem transportasi yang tertib, aman, selamat, nyaman, cepat, teratur, lancar dan dengan biaya yang terjangkau diperlukan masyarakat dalam mendukung aktifitasnya. Oleh sebab itu, penyelenggara sistem transportasi harus mengelola transportasi terutama transportasi publik secara efektif dan efisien serta memberikan kenyamanan kepada masyarakat.

Kota-kota besar di Indonesia seperti Jakarta, Bandung, Surabaya dan kota lainnya sudah banyak menerapkan moda terbaru ini yaitu Bus Rapid Transit (BRT) yang namanya akan berbeda-beda di setiap kota. Contoh Kota Jakarta, Bus Rapid Transit (BRT) yang diberi nama TransJakarta ini telah resmi beroperasi sejak 1 Februari 2004. TransJakarta dirancang karena sebagai moda transportasi massal pendukung aktivitas Ibu Kota yang sangat padat. Dengan jalur lintasan terpanjang di dunia $(251,2 \mathrm{~km})$, serta memiliki 260 halte yang tersebar dalam 13 koridor, Transjakarta yang awalnya beroperasi mulai pukul 05.00-pukul 22.00 WIB, kini beroperasi 24 jam di sebagian koridornya. Bus Rapid Transit disingkat BRT atau populer di Indonesia dengan sebutan busway adalah sistem transit massal berbasis bus yang memberikan mobilitas cepat, nyaman dan berbiaya rendah dalam pelayanannya sebagai angkutan dalam perkotaan. Pemerintah Kota Cirebon juga sudah menerapkan moda terbaru tersebut dengan nama Bus Trans Cirebon yang mulai beroperasi pada tanggal 12 April 2021. Dengan traportasi ini, diharapkan dapat menjadi salah satu alternative untuk mengurangi kemacetan, menunjang kelancaran dan kemudahan aktivitas masyarakat. Dan juga dapat merasakan kenyaman fasilitas yang disediakan dengan berbiaya rendah dan terjangkau.

Akan tetapi dari hasil wawancara dengan PT. Bima Inti Global selaku pengelola memang merasa masyarakat masih kesulitan dalam mendapatkan informasi mengenai rute, halte dan jadwal keberangkatan Bus Rapid Transit (BRT) Kota Cirebon maka dibutuhkan sistem untuk membantu dan memudahkan masyarakat dalam mendapatkan informasi. Dan juga berdasarkan pengamatan yang dilakukan dengan menaiki Bus Rapid Transit (BRT) Kota Cirebon, dapat dilihat juga didalam bus belum adanya informasi mengenai rute, halte dan jadwal keberangkatan tujuan selanjutnya.

Maka dari itu untuk mewujudkan hal tersebut penulis bermaksud merancang sebuah sistem informasi rute bus rapid transit Di Kota Cirebon sebagai penulisan proyek sistem informasi yang berjudul "Perancangan Sistem Informasi Rute Bus Rapid Transit (BRT) Di Kota Cirebon Berbasis Website" yang bertujuan mempermudah pengelola dan masyarakat atau pengguna Bus Rapid Transit (BRT) Kota Cirebon.

\section{KAJIAN PUSTAKA}

\subsection{Sistem Informasi}

Menurut Krismiaji dalam bukunya yang berjudul Sistem Informasi Akuntansi. Sistem informasi adalah cara-cara yang diorganisasi untuk mengumpulkan, memasukkan dan mengolah serta menyimpan data, dan cara-cara yang diorganisasi untuk menyimpan, mengelola, mengendalikan, dan melaporkan informasi sedemikian rupa sehingga sebuah organisasi dapat mencapai tujuan yang telah ditetapkan. (Krismiaji 2015, p16)

\subsection{Transportasi}

Menurut Papacostas (1987), transportasi didefinisikan sebagai suatu sistem yang terdiri dari fasilitas tertentu beserta arus dan sistem control yang memungkinkan orang atau barang dapat berpindah dari suatu temapat ke tempat lain secara efisien dalam setiap waktu untuk mendukung aktivitas manusia.

\subsection{Rute}

Rute merupakan ruas - ruas jalan yang dilalui dalam suatu trayek sehingga satu trayek dapat memiliki lebih dari satu rute. Rute angkutan umum biasanya ditempatkan di lokasi yang memang diperkirakan ada calon penumpang yang akan dilayani. Sistem jaringan rute yaitu sekumpulan rute yang bersama - sama 7 melayani kebutuhan masyarakat. Dalam sistem jaringan rute tersebut akan terdapat titik - titik dimana akan terjadi pertemuan dua rute atau lebih. Pada titik - titik yang dimaksud dimungkinkan pergantian rute, karena pada kenyataannya seorangpenumpang tidak selamanya dapat menggunakan hanya satu rute untuk perjalanan dari tempat asal ke tempat tujuan (Warpani, 2002). 


\subsection{Halte}

Berdasarkan Keputusan Direktur Jenderal Perhubungan Darat Nomor : 271/HK.105/DRJD/96 Halte adalah tempat perhentian kendaraan penumpang umum untuk menurunkan dan/atau menaikkan penumpang yang dilengkapi dengan bangunan.

\subsection{Bus Rapid Transit (BRT)}

Bus Rapid Transit (BRT) adalah suatu flesibel, moda dengan roda karet yang mempunyai transit yang cepat dan yang dikombinasikan station (halte), kendaraan, pelayanan, jalan dan elemen Intelligent Transportation System (ITS) dalam satu sistem yang terintegrasi dengan identitas yang kuat. (Levinson et al.2003, p.12).

\subsection{PT. Bima Inti Global}

PT.BIG (Bima Inti Global) bergerak dalam bidang logistic dan pariwisata adalah sebuah pioneer dari penyediaan armada angkutan / pengiriman barang umum via jalur darat untuk semua tujuan di Pulau Jawa. PT.BIG selalu berusaha meningkatkan kepuasan pelangggan. PT.BIG mengikuti program ISO 9001:2015 agar kepuasan pelanggan dapat ditingkatkan. Unit-unit yang disdiakan oleh PT.BIG adalah Truck Trailer (kapasitas muatan : 45 - 55 ton), Truck Tronton (kapasitas muatan : 30-35 ton) dan Truck Gandeng (kapasitas muatan : 40-45 ton). Unit-unit yang disediakan oleh PT.BIG juga dilengkapi oleh online system dan GPS sehinggan kami dapat selalu memberikan yang terbaik kepada pelanggan. Pada saat ini PT. Bima Inti Global tidak hanya menjalankan dari penyediaan armada angkutan / pengiriman barang umum via jalur darat untuk semua tujuan di Pulau Jawa saja, tapi pada tanggal 3 April 2021 PT Bima Inti Global diberi tugas untuk mengoperasikan Bus Rapid Transit (BRT). Terjadinya Kerjasama antara Dinas Perhubungan, PD Pembangunan dan PT Bima Inti Global.

\subsection{Struktur Organisasi}

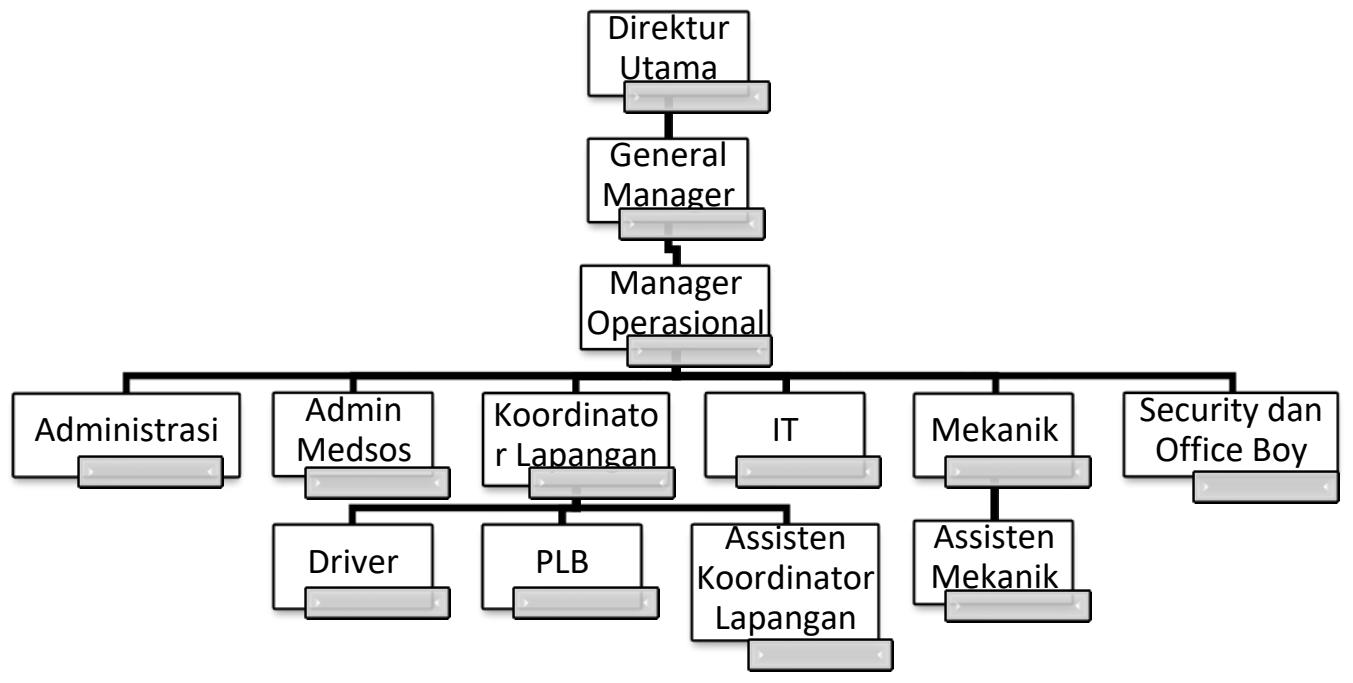

Gambar 1. Struktur Organisasi PT Bima Inti Global 


\section{METODE PENELITIAN}

3.1 Use Case Diagram

a. Admin

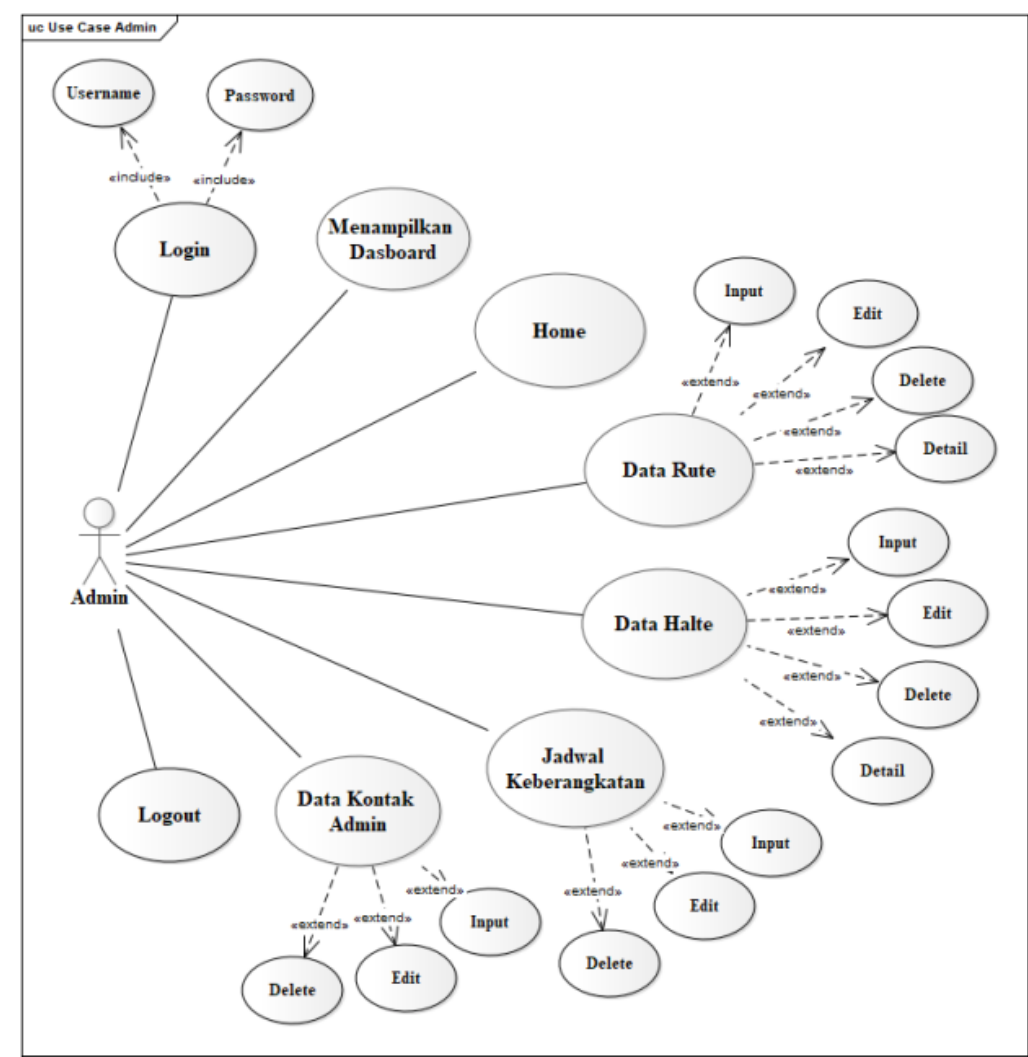

Gambar 2. Use Case Diagram Admin

b. Masyarakat

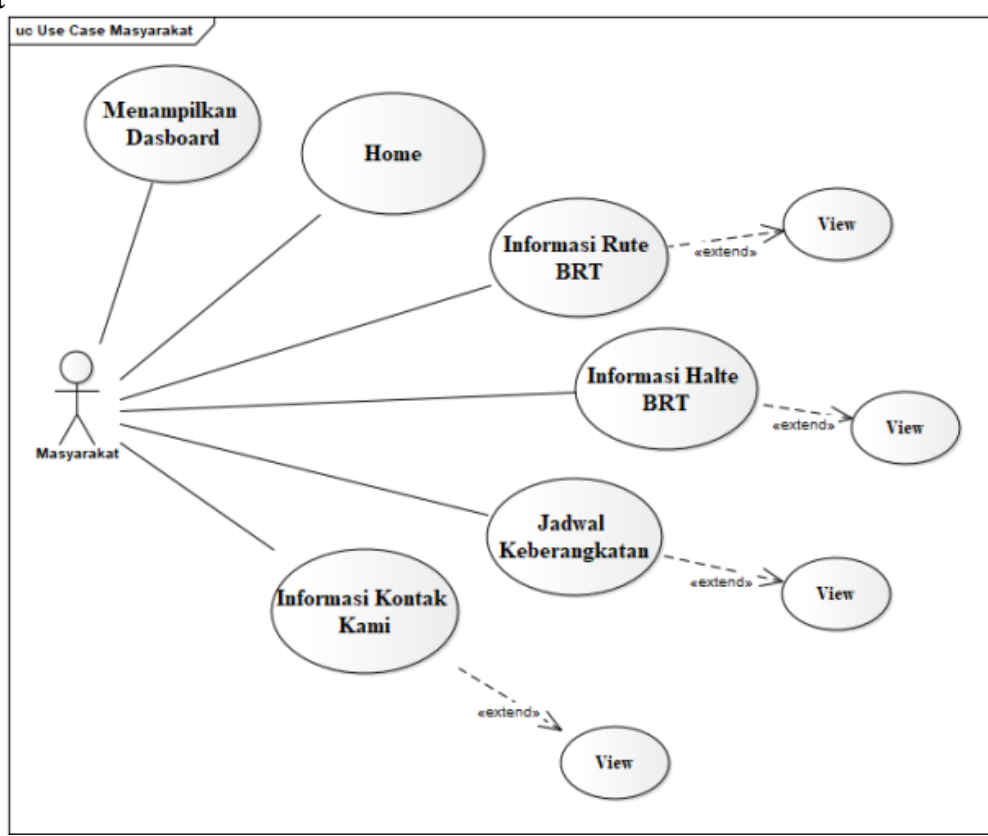

Gambar 3. Use Case Diagram Masyarakat 
JURNAL DIGIT Vol. 11, No.2 November 2021, pp.200 211

ISSN : 2088-589X

3.2 Activity Diagram

a. Admin

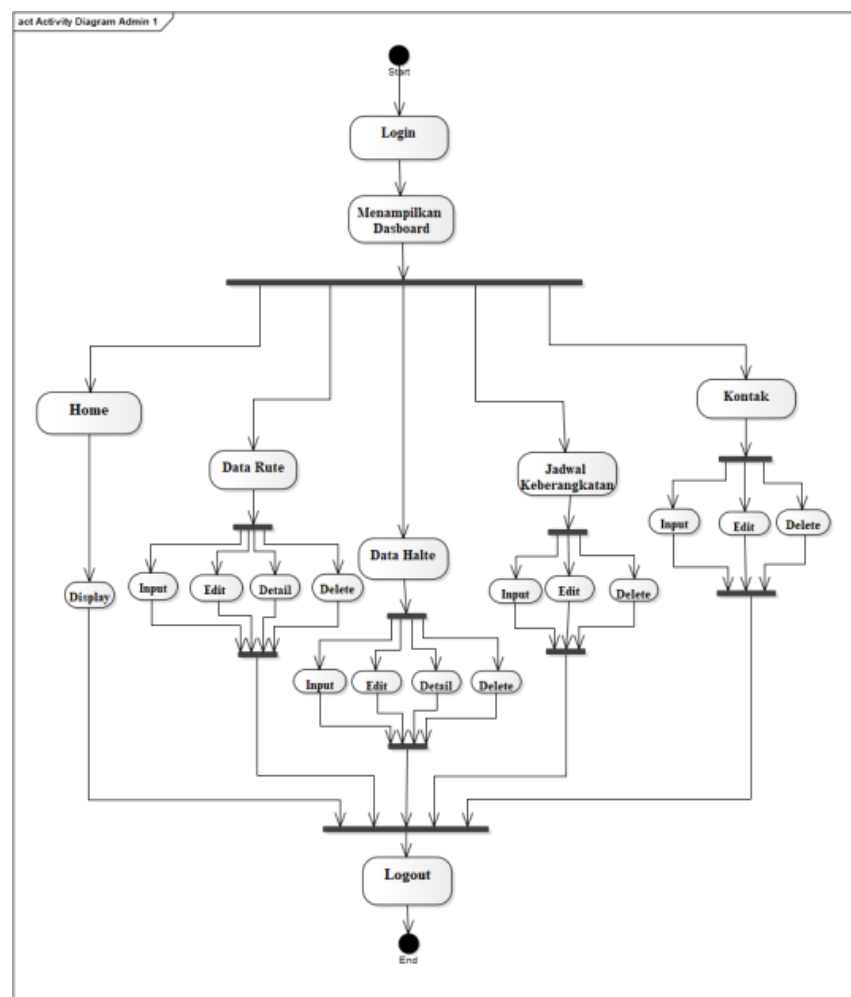

Gambar 4. Activity Diagram Admin

b. Masyarakat

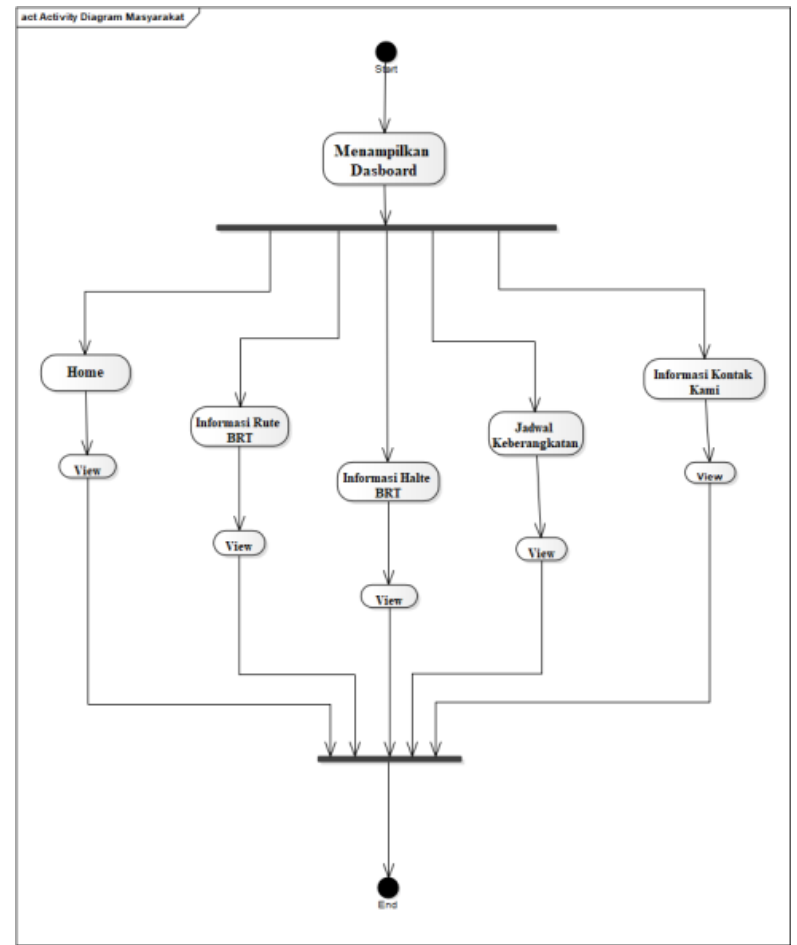

Gambar 5. Activity Diagram Masyarakat

Perancangan Sistem Informasi Rute Bus Rapid Transit (BRT) di Kota Cirebon Berbasis (Studi Kasus: PT. Bima Inti Global)-(Hendra Wijaya, Selvi Feliyanti, Lena Magdalena, Reza Ilyasa) 
3.3 Sequence Diagram

a. Admin

1) Kelola Data Rute

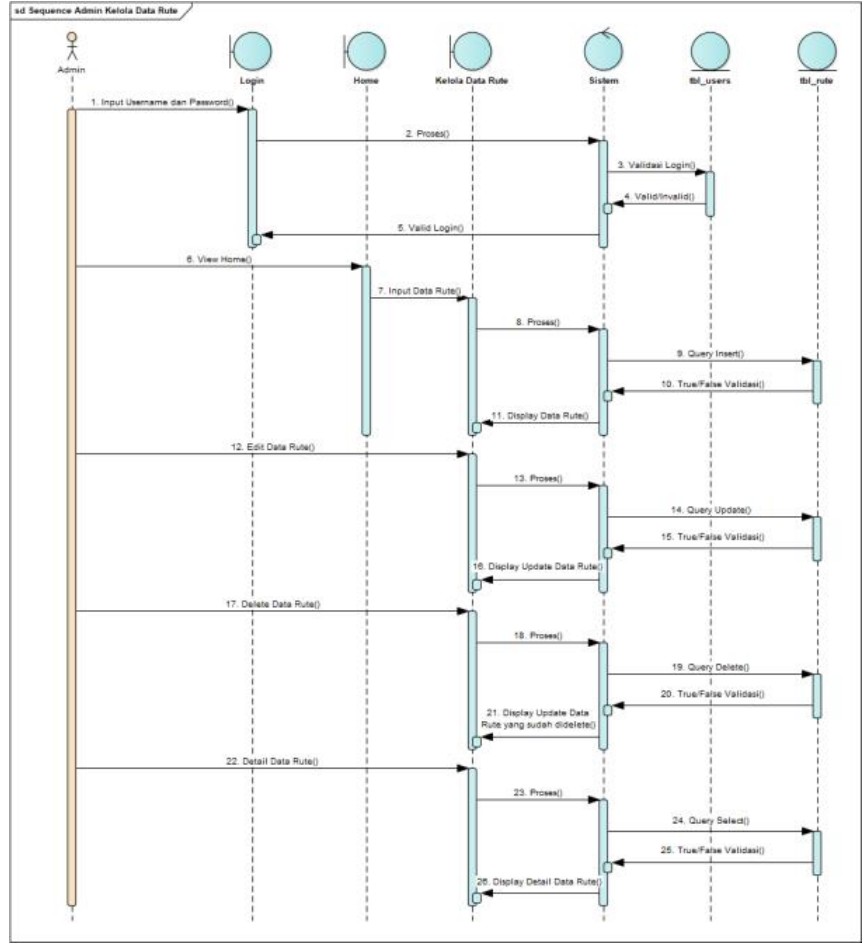

Gambar 6. Sequence Diagram Kelola Data Rute

2) Kelola Data Halte

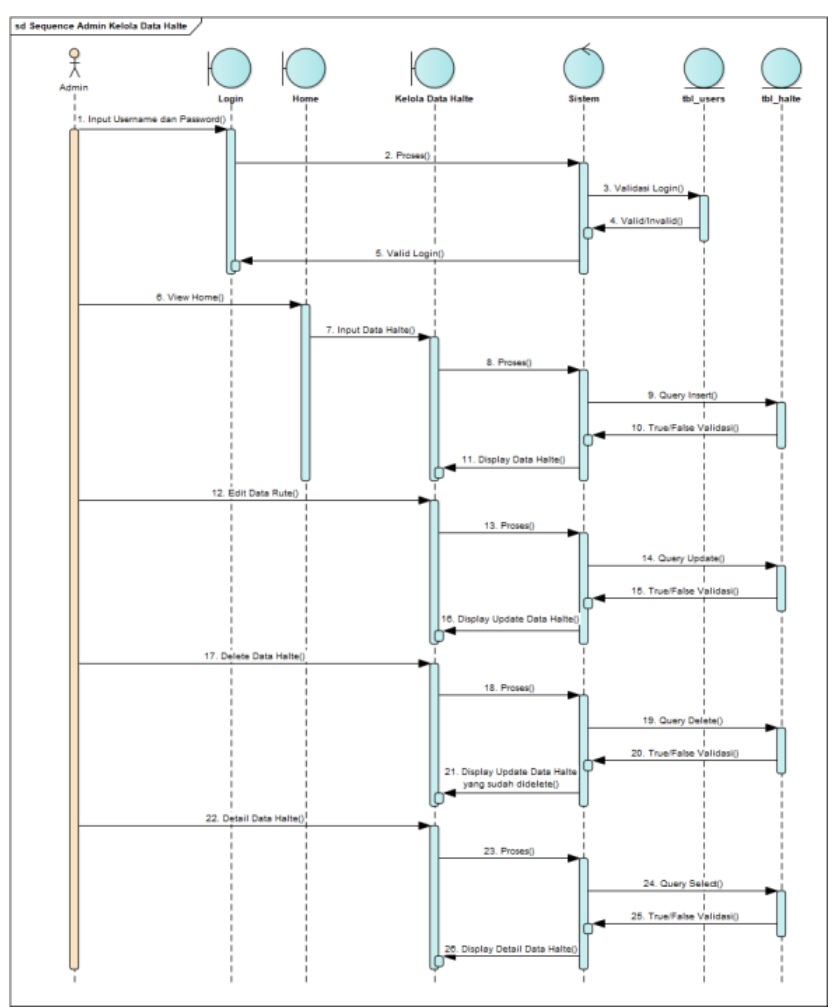

Gambar 7. Sequence Diagram Kelola Data Halte 
3) Kelola Jadwal Keberangkatan

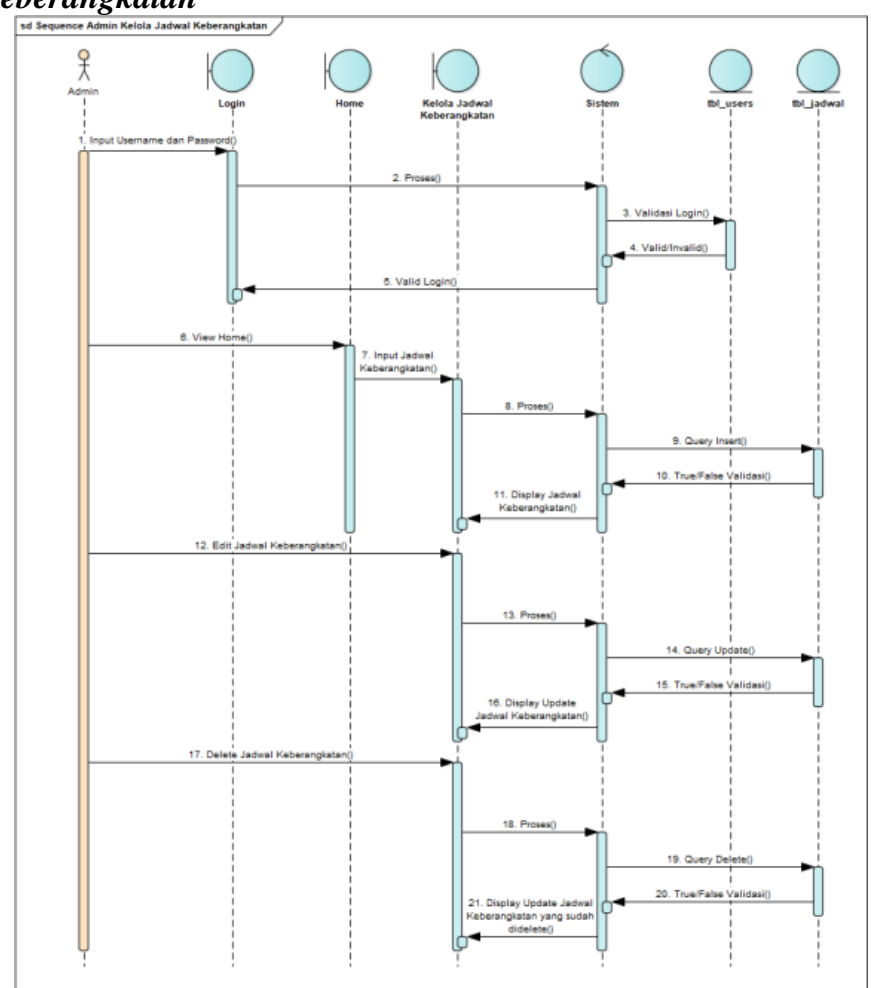

Gambar 8. Sequence Diagram Kelola Jadwal Keberangkatan

\section{4) Kelola Data Kontak Admin}

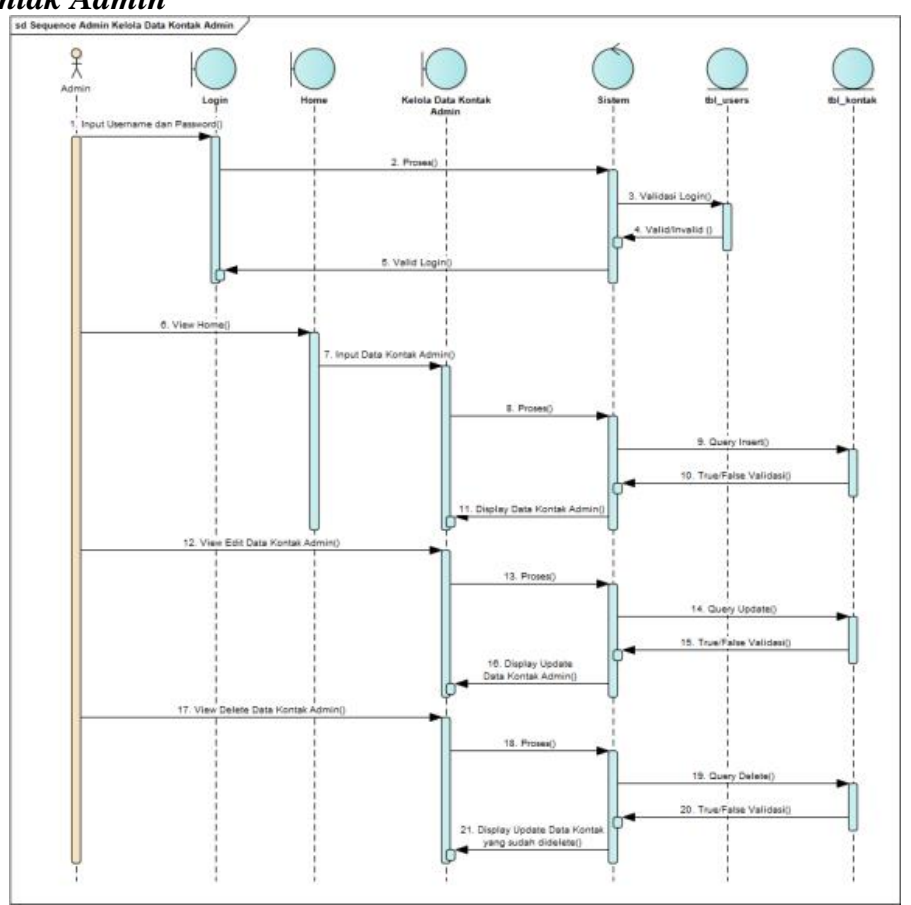

Gambar 9. Sequence Diagram Kelola Data Kontak Admin

Perancangan Sistem Informasi Rute Bus Rapid Transit (BRT) di Kota Cirebon Berbasis (Studi Kasus: PT. Bima Inti Global)-(Hendra Wijaya, Selvi Feliyanti, Lena Magdalena, Reza Ilyasa) 
b. Masyarakat

1) Informasi Rute BRT

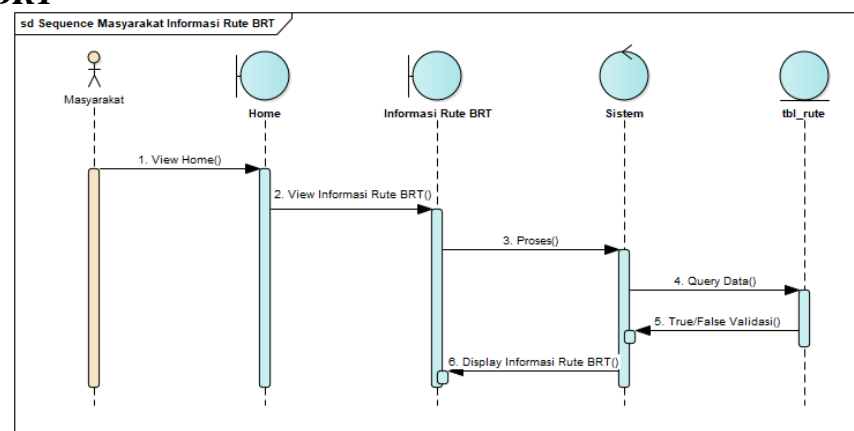

Gambar 10. Sequence Diagram Informasi Rute BRT

2) Informasi Halte BRT

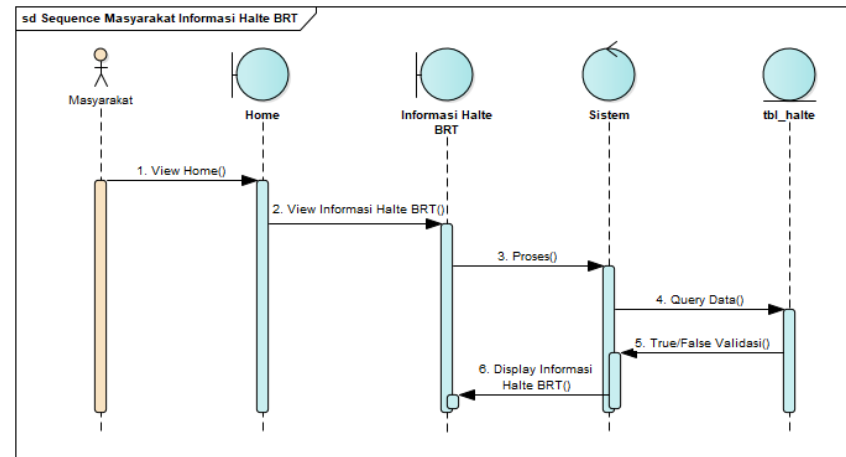

Gambar 11. Sequence Diagram Informasi Halte BRT

3) Jadwal Keberangkatan

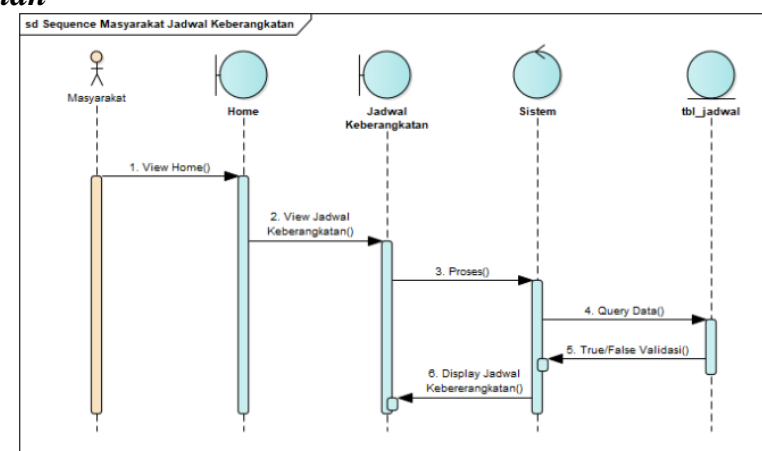

Gambar 12. Sequence Diagram Jadwal Keberangkatan

4) Informasi Kontak Kami

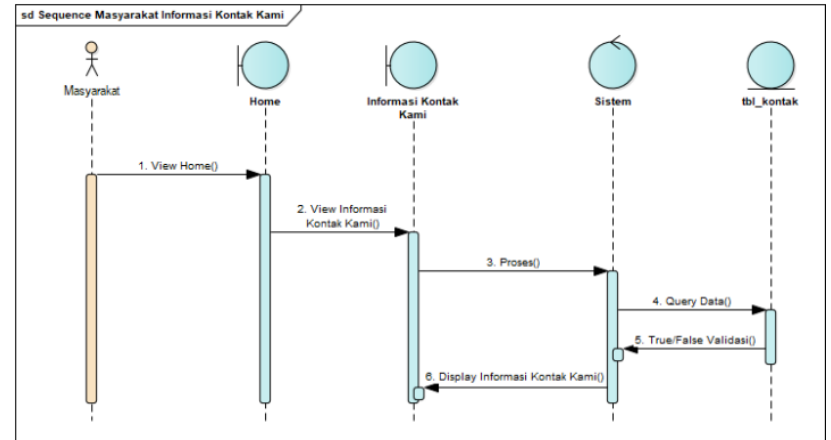

Gambar 13. Sequence Diagram Informasi Kontak Kami 
3.4 Class Diagram

a. Admin

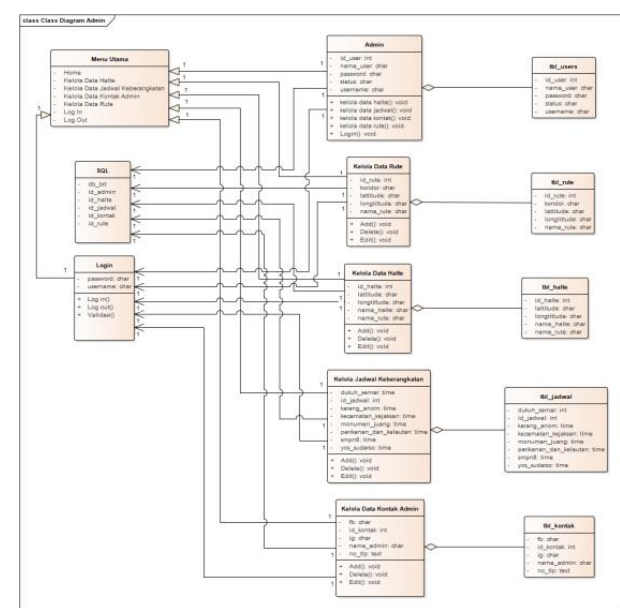

Gambar 14. Class Diagram Admin

b. Masyarakat

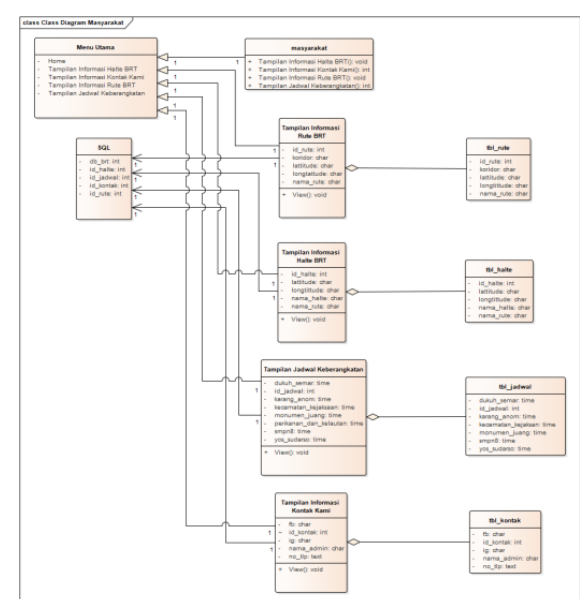

Gambar 15. Class Diagram Masyarakat

\section{HASIL DAN PEMBAHASAN}

4.1 Tampilan Halaman Website

a. Halaman Login Admin

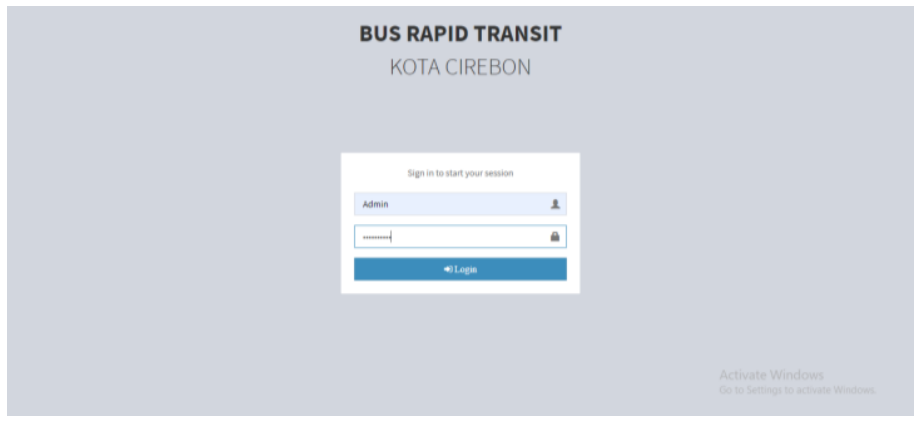

Gambar 16. Tampilan Halaman Login Bagian Admin

Perancangan Sistem Informasi Rute Bus Rapid Transit (BRT) di Kota Cirebon Berbasis (Studi Kasus: PT. Bima Inti Global)-(Hendra Wijaya, Selvi Feliyanti, Lena Magdalena, Reza Ilyasa) 
b. Halaman Menu Utama Admin

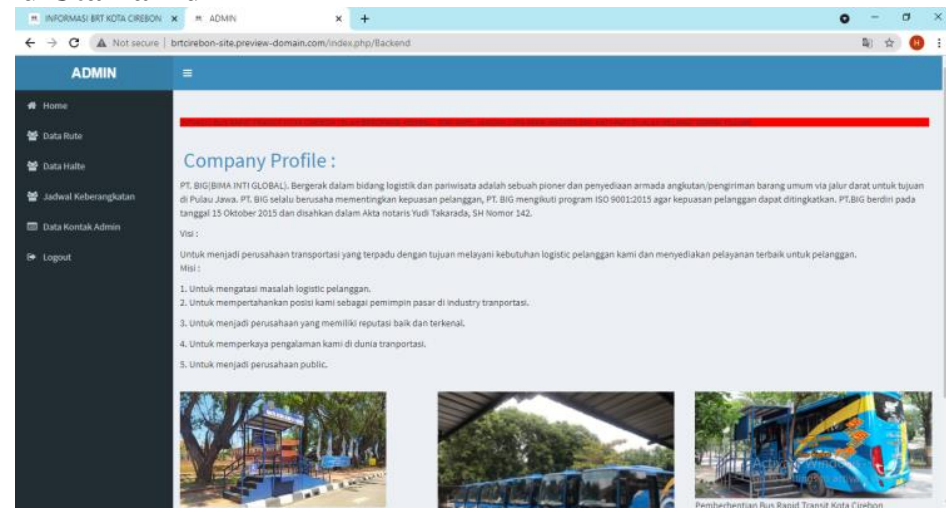

Gambar 17. Tampilan Halaman Menu Utama Admin

c. Halaman Menu Utama Masyarakat

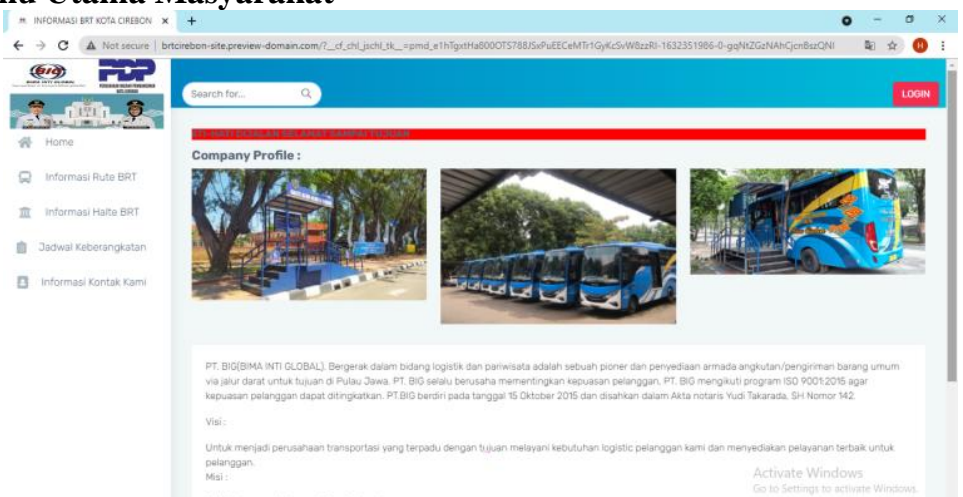

Gambar 18. Tampilan Halaman Menu Utama Masyarakat

\subsection{Halaman Output}

a. Informasi Rute BRT

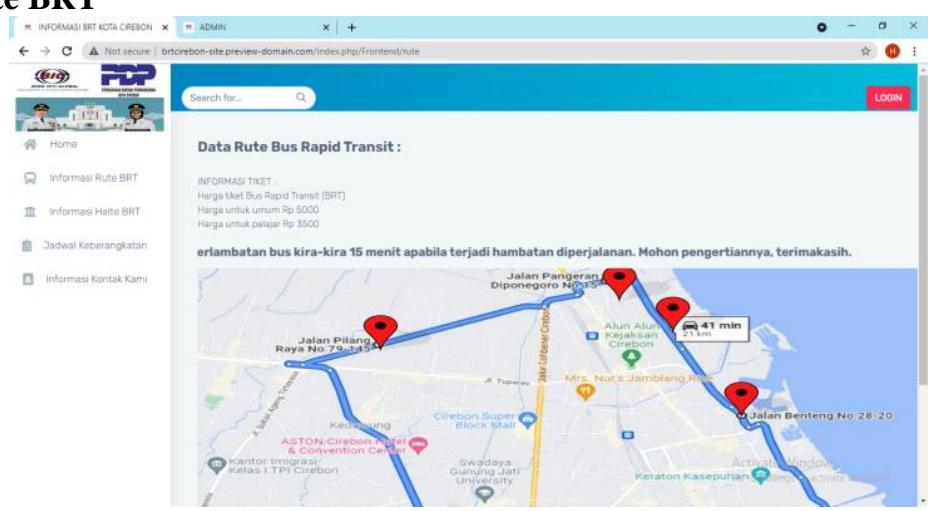

Gambar 19. Tampilan Informasi Rute BRT 
b. Informasi Halte BRT

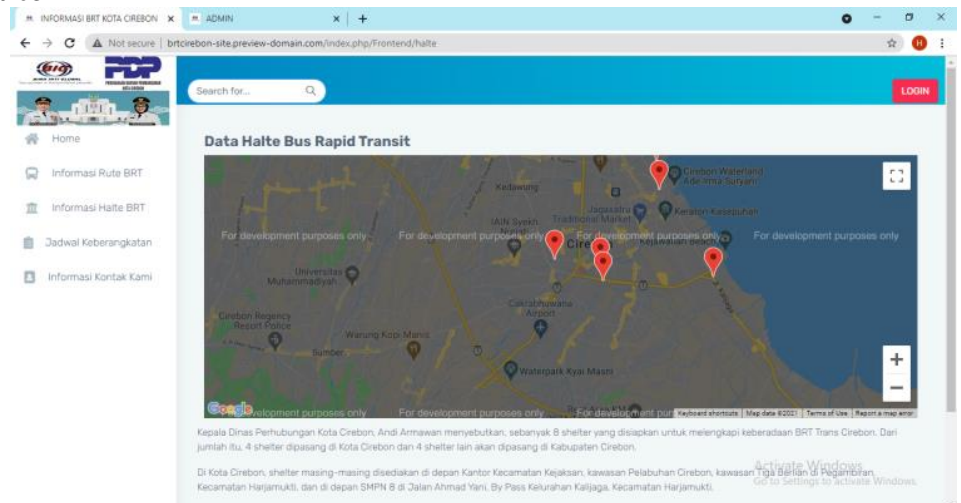

Gambar 20. Tampilan Informasi Halte BRT

c. Jadwal Keberangkatan

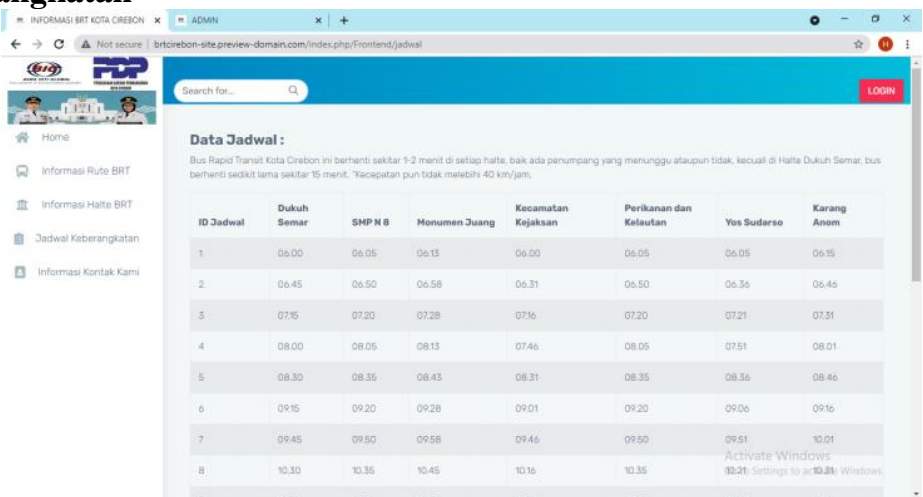

Gambar 21. Tampilan Jadwal Keberangkatan

d. Informasi Kontak Kami

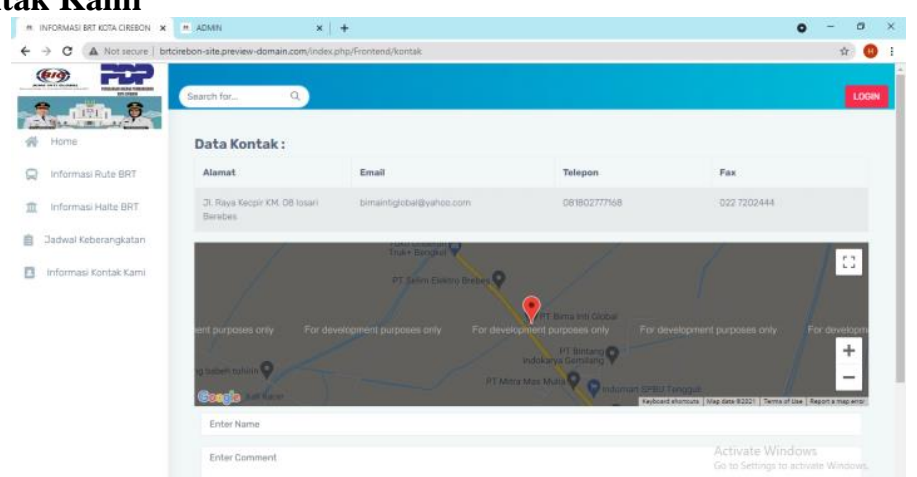

Gambar 22. Tampilan Informasi Kontak Kami

Perancangan Sistem Informasi Rute Bus Rapid Transit (BRT) di Kota Cirebon Berbasis (Studi Kasus: PT. Bima Inti Global)-(Hendra Wijaya, Selvi Feliyanti, Lena Magdalena, Reza Ilyasa) 


\section{KESIMPULAN DAN SARAN}

Berdasarkan hasil penelitian dan analisa serta perancangan yang telah dilaksanakan, maka dapat ditarik beberapa kesimpulan yaitu:

1. Membantu membuat sistem informasi rute bus rapid transit untuk dipakai masyarakat Cirebon.

2. Sistem ini membantu memudahkan masyarakat dalam mendapatkan informasi rute, halte dan jadwal keberangkatan bus rapid transit. Dengan adanya sistem ini juga memudahkan admin perusahaan dalam mengelola seperti tambah, edit dan hapus data rute, data halte, dan jadwal keberangkatan bus rapid transit.

3. Sistem berhasil dibuat. Dengan adanya sistem yang dibuat, dengan sistem google maps dapat membantu titik-titik koridor bus rapid transit yang ingin diketahui masyarakat.

\section{DAFTAR PUSTAKA}

[1] Krismiaji. (2015) Sistem Informasi Akuntansi Edisi keempat. Yogyakarta : Sekolah Tinggi Ilmu Manajemen YKPN.

[2] Anonim. 2017. Transportasi . dalam http://e-journal.uajy.ac.id/7732/3/TA213706. Diakses pada 13 Juli 2021.

[3] Warpani, S, 1990, Merencanakan Sistem Perangkutan, Penerbit ITB, Bandung.

[4] 1996. Keputusan Direktur Jenderal Perhubungan Darat No.271/HK.105/DRJD/96 Tentang Pedoman Teknis Perekayasaan Tempat Perhentian Kendaraan Penumpang Umum, Direktorat Jenderal Perhubungan Darat, Jakarta.

[5] Levinson, H., Zimmerman, S., Clinger, J., Rutherford, S., Smith, R.L., Cracknell, J., \& Soberman, R. (2003). Bus Rapid Transit, Volume 1: Case Studies in Bus Rapid Transit. Transit Cooperative Research Program (TCRP) Report 90, published by the Transportation Research Board, Washington. 